\title{
CONTRATO - PRAZO E PRORROGAÇÃO - EXERCICIO FINANCEIRO
}

- Em regra, as prazos dos contratos, cujas despeos correm à conta de créditos orçamentários, não podem exceder ao período financeiro, ou da execução do orçamento.

PROCESSO P. G. N. ${ }^{\circ} 2.895$

\section{ACóRDÃo}

Aviso n. 991 , de 27 de setembro findo, acompanhado de cópias do têrmo de 21 anterior, aditivo de prorrogação de contrato celebrado com a Viação Aérea Rio Grandense S. A., em julho de 1942, para execução de linhas aéreas (PG. 2.895). - O Tribunal converteu o julgamento em diligência : 1) para, através de têrmo aditivo, ser ajustado o prazo de vigência da prorrogação, que deverá ser igual ao contrato registrado na Sessão de 8 de setembro de 1942 (dessa data até 31-12-44 - cláusulas XII e XV); 2) - para ser enviada nova certidão da Lei de $2-3$, porque a existente está caduca; 3 ) - para apresentar prova de quitação do serviço militar por parte dos Diretores; e 4) para serem revalidados os selos aus documentos de fls. 27,28 e 29 . No julgamento do processo acima, quanto ao $10^{\circ} \mathrm{item}$, foram votos vencidos os Senhores Ministros Relator e OLIVEIRA VIANA. Votaram que o prazo feveria ser apenas de 1 ano, na ausência de lei especial. Os senhores Ministros José AMśRICO e BERNARDINo DE SOUSA votaram que êsse prazo deveria ser igual ao do contrato prorrogado. Verificado empate, o Presidente desempatou nos têrmos dos votos dos senhores Ministros José AMÉrico e BERNARdino dE SOUSA, isto é, que o prazo deverá ser igual ao do contrato prorrogado.

O Sr. Ministro Relator proferiu o seguinte voto :

“1 - Baseado no Decreto-lei n. 4.396, de 22 de junho de 1942, celebrouse, a 20 de julho do mesmo ano, entre a Diretoria da Aeronáutica Civil e a S. A. Emprêsa de Viação Aérea Rio Grandense (Varig), um contrato para a execução do tráfego em diversas linhas, no Estado do Rio Grande do Sul.

2 - Dispõe o referido decreto-lei, no art. $3 .^{\circ}$, letra $t$ :

"O contrato de concessão vigorará até 31 de dezembro de 1944 podendo ser prorrogado a juizo do Govêrno".

Incluiu-se, porém, na lavratura do contrato, uma cláusula ( $n^{\circ} \mathrm{XII}$ ) nestes têrmos :

"O presente contrato, que não importa em monspólio ou privilégio de espécie alguma, vigorará até 31 de dezembro de 1944, po- 
dendo ser prorrogado por simples decisão do Govêrno, pelo tempo que convier, prevalecendo essa faculdade até completar-se o prazo de seis anos".

3 - Dito contrato foi mandado registrar pelo Tribunal de Contas, em sessão realizada a 8 de setembro de 1942 .

$4-\mathrm{A} 1$ de fevereiro do corrente ano aquela Emprêsa pediu ao Sr. Ministro da Aeronáutica a prorrogação do contrato por três anos (fls. 26).

Com pareceres favoráveis ao pedido, dos Srs. Chefe da Divisão Legal (fl.. 32) e Diretor de Aeronáutica, submeteu-o à apreciação do Sr. Presidente da República (fls. 32 v.).

Remetido o processo ao Ministério da Fazenda, conforme determinara o Sr. Presidente da República (fls. 33), houve ali audiência da Procuradoria Geral da Fazenda Pública, manifestando-se o titular favoràvelmente à prorrogação solicitada (fls. 38).

$E^{\prime}$ o que também entende o Sr. Ministro da Fazenda, em devolvendo o processo ao Sr. Presidente da República, acompanhado da Exposição n..$^{\circ} 2.310$, de 9 de agôsto último (fls. 40).

5 - Lavrou-se, então, a 21 de setembro próximo findo, um têrmo ąditivo, de prorrogação do contrato, por três anos, de 1 de janeiro de 1945 a 31 de dezembro de 1947 (fls. 43), publicado no Diário Oficial, edição de 27 daquêle mês.

Nessa mesma data, o Sr. Ministro da Aercnáutica remeteu o têrmo aditivo ao Tribunal de Contas (fls. 52), ai opinando pelo seu registro o Corpo Instrutivo (fls. 53) e o Dr. Procurador (f1s. 53 v.).

6 - Em regra, os prazos dos contratos, cujas despesas correm à conta de créditos orçamentários, não podem exceder ao periodo financeiro, ou da execução do orçamento.

E' o que se infere do disposto no art. 777 , princípio, do Regulamento Geral de Contabilidade Pública.

Já vigorava igual critério anteriormente, de acôrdo com a Lei n. 3.018 , de 5 de novembro de 1880 , que estabelecia no

"Art. 19. O Govêmo não pode, sem autorização expressa do Poder Legislativo, fazer contratos por tempo excedente do ano financeiro, que estiver correndo, nem por serviços não contemplados na Lei de Orçamento vigente".

7 - Entretanto há exceções, previstas em lei, permitindo a celebração de contratos, cujos prazos possam ir além do exercício financeiro:

I - por tempo não excedente de três anos :

a) quando versarem sôbre construções, aquisições de material de guerra, fôtça luz de estabelecimentos militares, alugueres de casas e campos para invernadas e locaçóes de serviços (Lei n. $0^{\circ} 4.632$, de 6 de janeiro de 1923, ert. $46, \mathrm{n} . \circ \mathrm{V}$ );

b) quando versarem sôbre aquisições e reparos de material de guerra, combustível, fôrça e luz (Lei n. 4.793 , de 7 de janeiro de 1924, art. 45, n. ${ }^{\circ}$ );

II - por tempo não excedente de cinco anos :

a) de arrendamento de prédios;

b) de obras de grande vulto (Regulamento Geral de Contabilidade Pública, art. 767 , parágrafo único). 
8 - O Decreto-lei n. ${ }^{\circ} 4.398$, de 22 de junho de 1942 , não fixa o prazo para a prorrogação do contrato em causa.

Dêste modo, não pode ultrapassar de um ano a sua duração, isto é, fica adstrita à vigência do crédito srçamentário, à conta do qual correrá a despesa (Regulamento Geral de Contabilidade Pública, art. 777, princípio).

9 - Dir-se-á que, podendo o contrato "ser prorrogado a juízo do Govêrno", tem êle faculdade de determinar o prazo que juigar, conveniente à continuação do serviço.

A meu ver, aquela autorização tem apenas o efeito de poder o Govêrno prorrogar a concessão independentemente de concorrência pública.

A questão de prazo ficou subordinada à lei geral.

10 - Desde que a lei autoriza a prorrogação do contrato, a despesa deve ser considerada empenhada, como se procede em relação aos casos a que se refere o art 767, parágrafo único, do Regulamento Greral de Contabilidade Pública.

Prolonga-se a execução do contrato, inclusive quanto à forma de serem pagas as prestações devidas.

II - Assim sendo, voto no sentido de converter-se o julgamento em diligência a fim de, por meio de novo têrmo aditivo, modificar-se a cláusula primeira, reduzindo-se para um ano o prazo de prorrogação do contrato anterior, e, de acôrdo com o disposto no art 769 do citado regulamento, seren exibid s os documentos :

a) de quitação do serviço militar por parte dos diretores da Emprêsa (art. 23, n. V, do Decreto-lei n. 3.864 , de 21 de novembro de 1941);

b) da proporcionalidade de empregados brasileiros (art. $362, \$ 1 .{ }^{\circ}$, combinado com o art. 352, do Decreto-lei $n 0^{0} 5.452$, de 1 de maio de 1943 ).

Além disso, é necessário proceder-se à revalidação dos selos, fls. 27 a 30 (art. 62, letra b, n.o 2, do Decreto-lei n. 4.655 , de 3 de setembro de 1942).

Sala das Sessões, em 10 de outubro de 1944. - A. Alvim Filho, Relator".

A diversidade de interpretação quanto à maneira do se aplicar u in texto do Regulamento Geral de Contabilidade Pública mostra a necessidade de modificá-1o, adaptando-o aos interêsses do. Govêrno, cujos problemas de administração se apresentam aǵora mais complexos.

Entendem a Diretoria de Contabilidade (fls. 31 v:), a Divisão Legal do Ministério da Aeronáutica (ibidem) e a Procuradoria Geral da Fazenda Pública (fls. 35 a 39 ) que a "pnorrogação pedida não excede o prazo autorizado pelo Código de Contabilidade Pública que é, no máximo, de 5 anos".

O Sr, Ministro da Fazenda, na exposição n. ${ }^{\circ} 2.310$, de 9 de agôsto último (fls 40 ), prende-se à cláusula do contrato anterior, quando diz :

"O contrato de concessão vigorará até 31 de dezembro de 1944, podendo ser prorrogado a juízo do Govêrno.

O presente contrato, que não importa em privilégio ou monopótio de espécie alguma, vigırará até 31 de dezembro de 1944, podendo set prortogado por simples decisão do Govêrno, pelo tempo que convier, prevalecendo essa faculdade até completar-se o prazo de seis anos", (Os grifos são do Sr. Ministro da Fazenda).

- Tribunal de Contas se dividiu : o relator e o $\mathbf{S r}$. Ministro Oliverra VIANA votaram pela prorrogação do contrato, por um ano; os senhores Ministros José AMÉrico e Bernardino de Sousa, por igual tempo ao do contrato primitivo; os Srs. Ministros Oliveira Lima e Silvestre Péricles, pelo prazo estipulado no têrno aditivo, ou conforme entendesse o Govêrno. Verificando-se - empate, o Sr. Ministro Presidente votou de acôrdo com os Ministros José AMÉrioo e BERNARdino de SOUSA. - A. Alvim Filho. 